NBER WORKING PAPER SERIES

\title{
CAN INFLATION TARGETING WORK IN EMERGING MARKET COUNTRIES?
}

\author{
Frederic S. Mishkin \\ Working Paper 10646 \\ http://www.nber.org/papers/w10646
NATIONAL BUREAU OF ECONOMIC RESEARCH 1050 Massachusetts Avenue
Cambridge, MA 02138 \\ July 2004
}

\begin{abstract}
For presentation in a conference in honor of Guillermo Calvo, held on April 15 and 16, 2004 at the International Monetary Fund in Washington, DC. The views expressed in this paper are exclusively those of the author and not those of Columbia University or the National Bureau of Economic Research.The views expressed herein are those of the author(s) and not necessarily those of the National Bureau of Economic Research.
\end{abstract}

(C)2004 by Frederic S. Mishkin. All rights reserved. Short sections of text, not to exceed two paragraphs, may be quoted without explicit permission provided that full credit, including (C) notice, is given to the source. 
Can Inflation Targeting Work in Emerging Market Countries?

Frederic S. Mishkin

NBER Working Paper No. 10646

July 2004

JEL No. E5, F3

\section{$\underline{\text { ABSTRACT }}$}

This paper explores issues in emerging market countries to make inflation targeting work for them. It starts by outlining why emerging market economies are so different from advanced economies and then discuss why developing strong fiscal, financial and monetary institutions is so critical to the success of inflation targeting in emerging market countries. Then it discusses two emerging market countries which illustrate what it takes to make inflation targeting work well, Chile and Brazil. It then addresses a particularly complicated issue for central banks in emerging market countries who engage in inflation targeting: how they deal with exchange rate fluctuations. The next topic focuses on the IMF's role in promoting the success of inflation targeting in emerging market countries. The conclusion from this analysis is that inflation targeting is more complicated in emerging market countries and is thus not a panacea. However, inflation targeting done right can be a powerful tool to help promote macroeconomic stability in these countries.

Frederic S. Mishkin

Graduate School of Business

Uris Hall 619

Columbia University

New York, NY 10027

and NBER

fsm3@columbia.edu 
An important theme in Guillermo Calvo’s work has been that emerging market economies are very different from advanced economies, and this has important implications that need to be factored in when designing macroeconomic policies. For example, Guillermo (e.g., see Calvo, 1999a, Calvo, 2001 and Calvo and Mendoza, 2000) has been quite skeptical of inflation targeting as a monetary policy strategy for emerging market countries. ${ }^{1}$ He worried that allowing too much discretion to policymakers in the weak institutional environment of emerging market countries might lead to poor macroeconomic outcomes. I am known to be an advocate of inflation targeting, but I think that Guillermo’s concerns about inflation targeting's efficacy in emerging market countries need to be taken seriously.

Before starting it is important to make clear what an inflation targeting regime is all about. It comprises five elements: 1) the public announcement of medium-term numerical targets for inflation; 2) an institutional commitment to price stability as the primary goal of monetary policy, to which other goals are subordinated; 3) an information inclusive strategy in which many variables, and not just monetary aggregates or the exchange rate, are used for deciding the setting of policy instruments; 4) increased transparency of the monetary policy strategy through communication with the public and the markets about the plans, objectives, and decisions of the monetary authorities; and 5) increased accountability of the central bank for attaining its inflation objectives. The list should clarify one crucial point about inflation targeting: it entails much more than a public announcement of numerical targets for inflation for the year ahead. This is important in the context of emerging market countries because

\footnotetext{
him.

${ }^{1}$ Although I suspect that Guillermo may be more favorable now, but you will have to ask 
many of them routinely reported numerical inflation targets or objectives as part of the government's economic plan for the coming year, and yet their monetary policy strategy should not be characterized as inflation targeting, which requires the other four elements for it to be sustainable over the medium term.

In this paper, I explore what additional issues need to be addressed in emerging market countries to make inflation targeting work for them. I start by outlining why emerging market economies are so different from advanced economies and then discuss why developing strong fiscal, financial and monetary institutions is so critical to the success of inflation targeting in emerging market countries. Then I discuss two emerging market countries which illustrate what it takes to make inflation targeting work well, Chile and Brazil. I then address a particularly complicated issue for central banks in emerging market countries who engage in inflation targeting: how they deal with exchange rate fluctuations. The next topic focuses on the IMF's role in promoting the success of inflation targeting in emerging market countries. The conclusion from this analysis is that inflation targeting is more complicated in emerging market countries and is thus not a panacea. However, inflation targeting done right can be a powerful tool to help promote macroeconomic stability in these countries.

\section{WHY EMERGING MARKET ECONOMIES DIFFER FROM ADVANCED ECONOMIES}

In our paper on the choice of exchange rate regimes in emerging market economies (Calvo and Mishkin, 2003), Guillermo and I have outlined five fundamental institutional 
differences for emerging market countries that must be taken into account to derive sound theory and policy advice. These are:

- Weak fiscal institutions.

-Weak financial institutions including government prudential regulation and supervision.

- Low credibility of monetary institutions.

- Currency substitution and liability dollarization.

- Vulnerability to sudden stops (of capital inflows).

Advanced countries are not immune to problems with their fiscal, financial and monetary institutions, the first three items in the list above, but there is a major difference in the degree of the problem in emerging market countries. Weak fiscal, financial and monetary institutions make emerging market countries very vulnerable to high inflation and currency crises, so that the real value of money cannot be taken for granted. As a result, emerging market countries face the threat that domestic residents may switch to a foreign currency leading to currency substitution (Calvo and Végh, 1996). Currency substitution is likely to be due not only to past inflationary experience but also to the sheer fact that a currency likes the U.S. dollar is a key unit of account for international transactions. This phenomenon has induced the monetary authority to allow banks to offer foreign exchange deposits. In this fashion, a sudden switch away from domestic and into foreign money need not result in a bank run, since in the presence of foreign exchange deposits, such a portfolio shift could be implemented by simply changing the denomination of 
bank deposits. Otherwise, deposits would be drawn down to purchase foreign exchange, resulting in a bank run.

Foreign exchange deposits induce banks—-partly for regulatory reasons that prevent banks from taking exchange rate risk — to offer loans denominated in foreign currency, usually dollars, hence leading to what is called liability dollarization. As pointed out in Mishkin (1996) and Calvo (2001) liability dollarization is what leads to an entirely different impact of currency crises on the economy in emerging market versus advanced countries. In emerging market countries, a sharp real currency depreciation raises the value of liabilities in local currency, thus causing the net worth of corporations and individuals to fall, especially those whose earnings come from the nontradables sector. This serious negative shock to corporations and individuals' balance sheets, then increases asymmetric information problems in credit markets, leading to a sharp decline in lending and an economic contraction. Thus, liability dollarization (where the currency mismatch takes place in corporates' and households' balance sheets) may become a major problem for economies that are relatively closed and highly indebted (this has typically been the case in several emerging market countries after the capital-inflow episode in the first half of the 1990s; see Calvo, Izquierdo and Talvi, 2002). Under those circumstances, the monetary authority is likely to display "fear of floating” (see Calvo and Reinhart, 2002) i.e., a reluctance to allow free fluctuations in the nominal exchange rate, ${ }^{2}$ placing an additional constraint on emerging market countries' monetary policy. It should be noted, however, that not

\footnotetext{
${ }^{2}$ The main concern is fluctuations in the real exchange rate but, as is well known (see Mussa, 1986), the real exchange rate shows high correlation with the nominal exchange rate.
} 
all emerging market countries suffer from liability dollarization in a serious way (e.g., Chile, and South Africa, see Eichengreen, Hausmann and Panizza, 2002).

A dominant phenomenon in emerging market countries is a sudden stop, a large negative change in capital inflows, which, as a general rule, appear to contain a large unanticipated component (see Calvo and Reinhart, 2000). This phenomenon is mostly confined to emerging market countries. It likely hits only emerging market countries because of their weak fiscal and financial institutions, and it is only recently that it is being subject to systematic empirical analysis. Preliminary evidence suggests that there is a high degree of bunching of sudden stops across emerging market countries. This is especially evident after the Russian 1998 crisis, and the recent Enron et al Wall Street scandals. This leads to the conjecture that, to a large extent, sudden stops have been a result of factors somewhat external to emerging market countries as a group. It might have been triggered by crisis in one emerging market country, as the Russian crisis illustrates, but contagion across emerging market countries was likely due to difficulties experienced outside these countries, especially in world financial centers (for evidence about that, see Kaminsky, Reinhart and Vegh, 2003). To illustrate, a possible contagion mechanism is a liquidity crunch in a financial center triggered by margin calls following unexpected capital losses, which leads the financial center to dump emerging market securities or, at least, not to participate in biddings for new debt instruments issued by emerging market countries. Calvo (1999b) conjectures that this mechanism could explain the large negative impact that the Russian crisis had over all emerging markets.

The effect of sudden stops on individual countries is by no means uniform. In Latin America, for example, Argentina suffered a very serious dislocation, while neighboring Chile 
escaped relatively unscathed (although Chile has seen its growth rate fall by more than 50 percent). In Asia, Korea has had a strong recovery, while Indonesia is still reeling from the shock. Tentative analysis suggests that these different outcomes have much to do with initial conditions. Chile had low debt relative to Argentina and did not suffer from liability dollarization, while at the time of crisis most debt instruments in Argentina were denominated in U.S. dollars. On the other hand, even though both Korea and Indonesia suffered from foreign exchange debt, the former was able to socialize much of the financial problem (as a result Korea's debt climbed from about 12 to about 33 percent of GDP in 1996-8). Hence, once again, debt and currency mismatch appear to have played a crucial role in determining the depth of crisis.

In the following sections, we will see how the above institutional features make inflation targeting a more complicated exercise in emerging market economies than in advanced economies.

\section{DEVELOPING STRONG FISCAL AND FINANCIAL INSTITUTIONS}

Fiscal stability is a fundamental necessary condition for inflation control and hence inflation targeting. A key lesson from the "unpleasant monetarist arithmetic" discussed in Sargent and Wallace (1981) and the recent literature on fiscal theories of the price level (Woodford, 1994 and 1995) is that irresponsible fiscal policy puts pressure on the monetary authorities to monetize the debt, thereby producing rapid money growth and high inflation. If fiscal imbalances are large enough, monetary policy eventually becomes subservient to fiscal 
considerations (so-called fiscal dominance) and an inflation target would have to be abandoned or seriously modified.

Similarly, a safe and sound financial system is also a necessary condition for the success of an inflation targeting regime. A weak banking system is particularly dangerous. Once a banking system is in a weakened state, a central bank cannot raise interest rates to sustain the inflation target because this will likely lead to a collapse of the financial system. Not only can this cause a breakdown of the inflation targeting regime directly, but it can also lead to a currency collapse and a financial crisis that also erode the control of inflation. When markets recognize the weakness of the banking system, there will be a reversal of capital flows out of the country (a sudden stop) that will result in a sharp depreciation of the exchange rate which leads to upward pressures on the inflation rate. Moreover, as a result of the currency devaluation, which most likely accompanies the monetary expansion, the debt burden of domestic firms which are denominated in foreign currency rises, while the assets which are denominated in domestic currency do so at a much slower pace, thus leading to decline in net worth. As described in Mishkin (1996), this deterioration in balance sheets then increases adverse selection and moral hazard problems in credit markets, leading to a sharp decline in investment and economic activity, and ultimately a complete collapse of the banking system. The subsequent bailout of the banking system leads to a huge increase in government liabilities which will have to be monetized in the future (Burnside, Eichenbaum and Rebelo, 2001), thus undermining the inflation targeting regime. Unfortunately, the scenario outlined here has happened all too often in recent years as evidenced by the twin crises (currency and financial) in Chile in 1982, Mexico in 1994-95, East Asia in 1997, Ecuador in 1999, Turkey in 2000-2001. 
Fiscal imbalances can also lead to banking and financial crises that will blow out any monetary regime to control inflation. As outlined in Mishkin and Savastano (2001), large budget deficits may force the government to confiscate assets, particularly those in the banking system and this has indeed happened often in Latin America. The suspicion that this might occur, would then cause depositors and other creditors to pull their money out of the banking system, and the resulting banking crisis would then also cause a contraction of lending and the economy. This happened several times in Argentina's checkered history, with the most recent variant of this mechanism occurring in 2001. The Argentine banking system was generally in quite good shape until 2000, even though the economy had been in a recession for several years. The strength of the Argentine banking system was the result of a sophisticated prudential regulatory and supervisory regime put into place after the tequila crisis that made Argentina's prudential supervision one of the best in the emerging market world (e.g., see Calomiris and Powell (2000). Large budget deficits forced the Argentine government to look for a new source of funds, the banking system which was primarily foreign-owned. After Domingo Cavallo became Minister of the Economy in April 2001 and the central bank president, Pedro Pou, was forced to resign, prudential supervisory standards were weakened and banks were both encouraged and coerced into purchasing Argentine government bonds. With the decline in the value of these bonds as the likelihood of default on this debt increased, bank's net worth plummeted. The likely insolvency of the banks, then led to a classic run on the banks and a full-scale banking crisis by the end of 2001. The result was a collapse of currency, a devastating depression and an initial surge in inflation. 
The particular problems for inflation control arising from fiscal and financial sector imbalances are of course not unique to emerging market countries and are a concern in advanced economies. However, these problems are of a different order of magnitude for emerging market countries and so must be addressed at the outset if an inflation targeting regime is to be able to keep inflation under control. Fiscal reforms which increase transparency of the government budget and budget rules which help keep budget deficits from spinning out of control are needed to prevent the fiscal imbalances that can lead to a collapse of an inflation targeting regime. ${ }^{3}$

Avoiding financial instability requires several types of institutional reforms. First, prudential regulation of the banking and financial system must be strengthened in order to prevent these types of financial crises. ${ }^{4}$ Second, the safety net provided by the domestic government and the international financial institutions set up by Bretton Woods might need to be limited in order to reduce the moral hazard incentives for banks to take on too much risk. ${ }^{5}$ Third, currency mismatches need to be limited in order to prevent currency devaluations from destroying balance sheets. Although prudential regulations to ensure that financial institutions match up any foreign-denominated liabilities with foreign-denominated assets may help reduce currency risk, they do not go nearly far enough. Even when the banks have equal foreign-

${ }^{3}$ For a discussion of fiscal reforms, see Perry, et. al (2000) and Tanzi (2000).

${ }^{4}$ See Mishkin (2003) for a description of what financial policies help prevent financial crises in emerging market countries.

${ }^{5}$ For example, recent research, summarized in Demirguc-Kunt and Kane (2002), suggests that the spread of deposit insurance in emerging market countries has made banking crises more likely. Other-rather mixed-evidence about the incidence of moral hazard at the international level is provided by Dell'Ariccia et al. (2000) and Jeanne and Zettelmeyer (2001). 
denominated (dollar) assets and liabilities, if banks dollar assets are loans to companies in dollars who themselves are unhedged, then banks' are effectively unhedged against currency devaluations because the dollar loans become nonperforming when the devaluation occurs. ${ }^{6}$ Thus limiting currency mismatches may require government policies to limit liability dollarization or at least reduce the incentives for it to occur. ${ }^{7}$ Fourth, policies to increase the openness of an economy may also help limit the severity of financial crises in emerging market countries. The reason why openness may affect financial fragility is that businesses in the tradable sector have balance sheets which are less exposed to negative consequences from a devaluation of the currency when their debts are denominated in foreign currency. Because the goods they produce are traded internationally, they are more likely to be priced in foreign currency. Then a devaluation which raises the value of their debt in terms of domestic currency is also likely to raise the value of their assets as well, thus insulating their balance sheets from the devaluation. Moreover, as argued in Calvo, Izquierdo and Talvi (2002), the more open is the economy, the smaller will be the required real currency depreciation following a sudden stop. Therefore, although firms in the nontradable sector are exposed to balance sheet shocks if they are liability dollarized, the size of the shock is smaller, the more open is the economy.

One view is that the fiscal and financial reforms discussed above must be in place before inflation targeting can even be attempted (Masson, Savastano and Sharma, 1997). However,

${ }^{6}$ See Mishkin (1996) for how this occurred in Mexico and Garber (1999) for a discussion of how the prudential regulations for Mexican banks to have a matched book did not protect them from currency risk.

${ }^{7}$ Recent papers by Caballero and Krishnamurthy (2002) and Jeanne (2002) suggest that de-dollarization may require a major overhaul of the domestic financial sector. 
although fiscal and financial stability are necessary conditions for inflation control, I think the view that these reforms are prerequisites for attempting an inflation targeting regime in emerging market countries is too strong. Because inflation targeting commits the government to keeping inflation low, it can be argued (Brash, 2000, and Bernanke, Laubach, Mishkin and Posen, 1999) that inflation targeting can help promote fiscal and financial reforms because the it now becomes clearer that the government must support these reforms if the inflation targeting regime is to be successful. Also a commitment to inflation control by the government makes it harder for the government to advocate loose fiscal policy because it is clearly inconsistent with the inflation target. However, institution of an inflation targeting regime by no means insures fiscal and financial reforms. If an inflation targeting regime is to be sustainable, a commitment to and work on these reforms is required when an inflation targeting regime is implemented.

\section{DEVELOPING STRONG MONETARY INSTITUTIONS}

Two underlying monetary institutions are necessary for the ability of the monetary authorities to keep inflation under control. The first is a public and institutional commitment to price stability as the overriding long-run goal of monetary policy. The institutional commitment can be written into law as it is in central bank legislation in many countries, most prominent among which are the EMU countries, and this is clearly helpful in giving a mandate to the central bank to control inflation. Inflation targeting takes this institutional commitment even further by defining what is price stability more specifically by providing a numerical inflation 
target as the objective for monetary policy. However, it is important to recognize that laws may matter less than the general public and politicians' commitment to support price stability. Here past history matters. Many emerging market countries have had a history of poor support for the price stability goal and since laws are easily overturned in these countries, it is not clear that laws will be sufficient.

The second institutional arrangement necessary for the success of inflation targeting is a public and institutional commitment to instrument independence of the central bank. ${ }^{8}$ Instrument independence means that the central bank is prohibited from funding government deficits, has to be allowed to set the monetary policy instruments without interference from the government and the members of the monetary policy board must be insulated from the political process by giving them long-term appointments and protection from arbitrary dismissal. There is a large literature on central bank independence and the forms that it takes (see Cukierman, 1992 and Forder 2000 for a recent survey), but again what is written down in the law may be less important than the political culture and history of the country. The contrast between Argentina and Canada is instructive here. Legally, the central bank of Canada does not look all that independent because the government has the ultimate responsibility for the conduct of monetary policy. In the event of a disagreement between the Bank of Canada and the government, the minister of finance can issue a directive that the bank must follow. However because the directive must be specific and

${ }^{8}$ There is an important distinction between goal and instrument independence (Debelle and Fischer, 1994 and Fischer, 1994). Instrument independence is the ability of the central bank to set monetary policy instruments without government interference, while goal independence means that the monetary authorities set the goals for monetary policy. The standard view in the literature is that central banks should have instrument but not goal independence. 
in writing, and because the Bank of Canada is a trusted public institution, a government override of the bank is likely to be highly unpopular and this will rarely occur. Thus in practice the Bank of Canada is highly independent. In contrast, the central bank of Argentina was highly independent from a legal perspective. However, this did not stop the Argentine government from forcing the resignation of the highly respected president of the central bank Pedro Pou in April of 2001 and his replacement with a president who would do the government's bidding. Indeed, it is unimaginable in countries like Canada, the United States or in Europe, that the public would tolerate the removal of the head of the central bank in such a manner, and indeed I do not know of any case of this happening in recent history. ${ }^{9}$ Thus a strong legal commitment to central bank independence without genuine public and political support for this independence, may not be enough to ensure monetary policies that will focus on inflation control in many emerging market countries.

An important advantage of inflation targeting is that it allows the monetary authorities some discretion and flexibility to use monetary policy to cope with shocks to the domestic economy. Indeed, as argued by Fraga, Goldfajn and Minella (2003), this flexibility is even more important in emerging market countries because they are subject to larger shocks. Inflation targeting regimes typically have built in flexibility to allow them to achieve their inflation target over longer horizons and are better characterized as “flexible inflation targeting” as is described in Svensson (1997) and Bernanke, Laubach, Mishkin and Posen (1999). This advantage of

${ }^{9}$ However, except for the Great Depression, advanced countries have not been hit by equally large shocks as in Argentina. Thus, the stability of the central bank in advanced countries may be partly explained by the size of the shocks and, in particular, the general absence of sudden stops. 
inflation targeting is also its weakness. Critics of inflation targeting, of whom Guillermo has been a prominent one (e.g., Calvo, 1999a, Calvo, 2001 and Calvo and Mendoza, 2000), have argued that inflation targeting may allow too much discretion to monetary policy and so may not provide a sufficient nominal anchor. However, as pointed out in Bernanke and Mishkin (1997) inflation targeting should be seen as a regime of "constrained discretion". Transparent discussions of the conduct of monetary policy can make it more difficult for the central bank to follow overly expansionary monetary policy, while accountability means that the central bank pays a high price if it engages in discretionary policy that leads to high inflation. However, Guillermo is quite quite correct that inflation targeting is no panacea. In order for inflation targeting to work to constrain discretion, it has to be supported by the public and the political process. Inflation targeting can help focus the public debate so that it supports a monetary policy focus on long-run goals such as price stability as has occurred in many inflation targeting countries (Bernanke, Laubach, Mishkin and Posen, 1999). However, these benefits require even more transparency and excellent communication skills on the part of the central bank in the more politically complicated environment in emerging market countries. Even excellent communication may not be enough if the political environment is incapable of supporting an independent central bank that focuses on inflation control.

TWO CASE STUDIES OF INFLATION TARGETING IN EMERGING MARKET COUNTRIES: THE CHILEAN AND BRAZILIAN EXAMPLES 
Despite the challenges to getting inflation targeting to work successfully, inflation targeting has been successfully in promoting macroeconomic stability in a number of emerging market countries. Here we will look at two case studies, Chile and Brazil, that illustrate that institutional development along the lines discussed above has been critical to the success of inflation targeting in the emerging market context.

Chile is the poster child for inflation targeting regimes in emerging market countries because it has had great success in lowering inflation to levels found in advanced countries, while at the same time experiencing very rapid economic growth. ${ }^{10}$ From 1991, when the inflation targeting regime started, to the present, Chile has been able to lower inflation rates from above $20 \%$ to around $2 \%$ currently. Over the same period, output growth has been very high, averaging 6\% per year from 1991 to 2002. However, it is important to emphasize that the success of Chile's inflation targeting regime has been based on development of the requisite institutions we have discussed here. Over the 1991-2002 period Chile's budget surplus averaged a little under $1 \%$ of GDP. In addition, due largely to the measures taken in the aftermath of the severe banking crisis in the early 1980s (costing over 40\% of GDP), Chile developed banking regulation and supervisory practices that are among the best in the emerging market world (Caprio, 1998) and are viewed as comparable to those found in advanced countries. As a result, even during the tequila crisis of 1995, the Russian meltdown of 1998 and the current difficulties in Latin America, the soundness of Chile's financial system has never come into question. The controls on short-term capital inflows have also been cited as another important factor behind the

\footnotetext{
${ }^{10}$ For those of you who don't know this expression, a poster child is a beautiful, but disadvantaged, child that is put on a poster (or advertisement) for a charity in order to stimulate donations.
} 
relative stability of the Chilean economy in the 1990s. However, these controls are very controversial and it is not at all clear that they have made a significant contribution to Chile's success (de Gregorio, Edwards and Valdes, 2000 and Edwards, 1999).

Chile also has worked on developing strong monetary institutions. In 1989 Chile passed new central bank legislation (which took effect in 1990 just before the start of the inflation targeting regime) that gave independence to the central bank and mandated price stability as its primary objective. Indeed, as pointed out in Landerretche et al. (1999) Chile only gradually hardened up its inflation targeting regime over time, with the announced inflation objective initially being interpreted more as official inflation projects rather than formal or "hard" targets. Only after the central bank already had some success with disinflation by 1994 did the inflation projections become hard targets with the central bank accountable for meeting them. Furthermore, until August 1999, Chile had an exchange-rate band around a crawling peg and in 1998 it actually fixed its exchange rate for a time (although this was a mistake that will be discussed in the next section and was reversed later). ${ }^{11}$ Thus Chile has exhibited some "fear of floating" along the lines described by Calvo and Reinhart (2002). Indeed, Chile's inflation targeting regime should be seen as very evolutionary, with Chile going to a full-fledged inflation targeting regime only in May 2000 (see Mishkin and Savastano, 2002).

Brazil implemented inflation targeting shortly after the real collapsed in January 1999. After much confusion, in early February the new central bank president, Arminio Fraga, announced that Brazil would soon be adopting an inflation targeting strategy, while at the same time putting his

${ }^{11}$ See Mishkin and Savastano (2002). 
money where his mouth was by increasing the interbank policy interest rate by 600 basis points to 45\%. On June 21, the President of Brazil issued a decree instituting an inflation targeting framework. This framework included all the features of a full-fledged inflation targeting regime, including: 1) the announcement of multi-year inflation targets (with explicit numerical targets for the 12-month rate of inflation in the years 1999, 2000 and 2001, and a commitment to announce the targets for 2002 two years in advance; 2) assigning the National Monetary Council the responsibility for setting the inflation targets and tolerance ranges based on a proposal by the Minister of Finance; 3) giving to the central bank of Brazil full responsibility to implement the policies needed to attain the inflation targets; 4) establishing procedures to increase the central bank’s accountability (specifically, if the target range is breached, the central bank president would have to issue an open letter to the Minister of Finance explaining the causes of the deviation, the measures that will be taken to eliminate it, and the time it will take to get inflation back inside the tolerance range) and 5) taking actions to improve the transparency of monetary policy (concretely, the central bank was requested to issue a quarterly Inflation Report modeled after that produced by the Bank of England). Brazil's adoption of inflation targeting was not preceded by prior development of all the fiscal, financial and monetary reforms that were discussed earlier. First, the 1999 collapse of the real can be attributed to the inability of the Brazilian government to put its fiscal house in order: the currency crisis was prompted by a moratorium on debt payments at the beginning of January by the governor of a Brazilian state, Minas Gerais. Brazil then did take steps to improve its fiscal balances under its program with the IMF, but there were still doubts about the durability of Brazil’s fiscal reforms (e.g., see Mishkin and Savastano, 2002.) On the other hand, Brazil did have a strong banking system because it had undergone a major restructuring following the banking crisis of 
1994-96 (see Caprio and Klingebiel, 1999.) The independence of Brazil’s central bank and the commitment to price stability, however, were not clear cut. Both were based on a presidential decree and confidence in a superb central bank president, but not on a more formal commitment based on legislation.

To the surprise of many, the inflation targeting strategy seemed to work. The initial inflation targets were set at $8 \%$ for $1999,6 \%$ for 2000 and $4 \%$ for 2001 , with a tolerance range of $\pm 2 \%$. There was a remarkably small pass-through from the large depreciation of the real (which fell by $45 \%$ on impact and thereafter stabilized at $30 \%$ below its pre-devaluation level) for several months, the output contraction was contained (in fact, annual GDP grew by almost 1 percent in 1999), Brazil was not cut-off from external financing--though there was some "arm twisting" involved-- and there were no major bank runs. By March 1999, asset prices had started to recover, the real appreciated and the central bank found room to lower interest rates--which it did, quite aggressively (from a high of $45 \%$ to below $20 \%$ in a seven-months period). Inflation and the exchange rate remained subdued through October, when the monthly inflation rate rose to $1.2 \%$, the largest monthly increase since June 1996, and the exchange rate crossed, briefly, the then “critical” mark of R $\$ 2.00$ per U.S. dollar. In the event, inflation in 1999 reached 8.9\%, above the 8\% target for the year but well within the 2 percent tolerance range; during 2000 inflation continued falling, and closed the year right at the 6\% mid-point target set by the central bank in mid-1999. However, in 2001, the inflation rate exceeded the $4 \%$ inflation target by more than the $2 \%$ tolerance range, ending up at $7.7 \%$.

The weakness of some aspects of the institutional framework for fiscal and monetary policy did come back to haunt the inflation targeting regime in Brazil. In the runup to the presidential election in October 2002, the market had concerns that the front-runner, Lula, would weaken fiscal 
and monetary institutions. Lula had made statements that seemed to indicate that once in office he would encourage fiscal policy to be highly expansionary and would not take steps to prevent a possible default on Brazil's foreign debt. He also indicated that he would not reappoint the highly respected president of the central bank, Arminio Fraga, and Lula's commitment to the independence of the central bank, price stability and the inflation targeting regime was far from clear. Not surprisingly, the lack of market confidence in Lula, who was then elected President led to a sharp depreciation of the Brazilian real and a sharp upward spike to inflation to $12.5 \%$, which substantially overshot the inflation target of 3.5\% for 2002. The impact of the Brazilian election on the inflation targeting regime illustrate that weak fiscal and monetary institutions are likely to create severe problems for an inflation targeting regime.

However, the response of the Brazilian government and central bank to the overshoots of the inflation targets illustrates that inflation targeting can help keep inflation under control in the face of big shocks like the real depreciation in 2002. As noted above, under the presidential decree that gave birth to inflation targeting, the Banco Central do Brasil was required to submit an open letter to the Ministry of Finance explaining the causes of the breach of the inflation target and what steps would be taken to get the inflation rate back down again. Given the large overshoot of the inflation targets, central bank credibility was on the line and the Banco Central do Brasil performed brilliantly. It explained how it would modify its inflation targets and what inflation path it would shoot for in the future with a very high degree of transparency (see Fraga, Goldfajn and Minella, 2003). First it explained why the exchange rate had overshot, and made explicit estimates of the size of the shocks and their persistence. It estimated the regulated-price shock to be $1.7 \%$ and estimated the inertia from past shocks to be $4.2 \%$ of which $2 / 3$ was to be accepted, resulting in a 
further adjustment of $2.8 \%$. Then the central bank added these two numbers to the previously announced target of $4 \%$ to get an adjusted inflation target for 2003 of $8.5 \%(=4 \%+1.7 \%+2.8 \%)$. The adjusted target was then announced in the open letter sent to the Minister of Finance in January 2003, which explained that getting to the non-adjusted target of $4 \%$ too quickly would entail far too high a loss of output. Specifically, the letter indicated that an attempt to achieve an inflation rate of $6.5 \%$ in 2003 would be expected to entail a decline of $1.6 \%$ of GDP, while trying to achieve the non-adjusted target of $4 \%$ would be expected to lead to an even larger decline of GDP of 7.3\%.

The procedure followed by the Banco Central do Brasil was a textbook case for central bank response to shocks in emerging market countries. First the procedure had tremendous transparency, both in articulating why the initial inflation target was missed, but also how the central bank was responding to the shock and plans to return to its longer-run inflation goal. This degree of transparency helped minimize the loss of credibility from the target miss and the need to adjust the short-term inflation target. Second, the central bank recognized that not adjusting the inflation target was just not credible because the market and the public clearly recognized that inflation would overshoot the initial target. Thus adjusting the target was absolutely necessary to retain credibility for the central bank, because to do otherwise would have just signaled to the markets that the central bank was unwilling to be transparent. Third, by discussing alternative paths for the inflation rate and why the particular path using the adjusted target was chosen, the central bank was able to demonstrate that it was not what Mervyn King (1996) has referred to as an "inflation nutter” who only cares about controlling inflation and not about output fluctuations. By its procedure of outlining that lower inflation paths would lead to large output losses, the Banco Central do Brasil demonstrated that it was not out of touch with the concerns of the public because it indeed does care 
about output losses, just as the public and the politicians do. This procedure is then likely to promote public and political support for central bank independence.

The outcome from this episode has been very favorable. After the initial spike, Brazil’s inflation rate and interest rates have been coming down rapidly. From its level of 12.5\% in 2002, the inflation rate fell to $9.3 \%$ by the end of 2003 , which is within the central bank tolerance range for the adjusted inflation target of 8.5\%. Market expectations of inflation have also dropped dramatically and now suggest that the market expects the central bank to meet its inflation targets in 2004. The interbank policy interest rate has also fallen from $26.5 \%$ in June 2003 to $16.3 \%$ in February 2004. Also after the initial decline in GDP, the Brazilian economy has begun growing again.

The Brazilian central bank has not been able to do this on its own. Given the discussion in this paper, an important component of a successful response to an inflation shock of this magnitude is growing confidence in government fiscal policy. President Lula has surprised many of his detractors by supporting measures to maintain fiscal discipline. He supported and got legislation passed in August 2003 to reform the public pension system to make it fiscally sustainable. His government has also pursued conservative spending policies that have resulted in a primary budget surplus in 2003 of $4.3 \%$ of GDP which is above the target of $4.25 \%$ requested by the IMF. Of course there are still concerns about how Brazil will proceed in the future. A new central bank law that would strengthen the independence of the Banco Central do Brasil and would provide a firmer institutional basis for inflation targeting has not yet been passed. Also given the pressures on the Lula government from the left, continuing fiscal responsibility is not completely assurred. 
The examples of Chile and Brazil illustrate that inflation targeting is indeed feasible in emerging market economies, despite their more complicated political and economic environment. Inflation targeting has been able to provide a strong nominal anchor that can keep inflation expectations in check. However, this requires not only a focus on good communication and transparency by the central bank, but also supportive policies to develop strong fiscal, financial and monetary institutions. The Brazilian case suggests that these policies do not have to be fully in place when inflation targeting is adopted for it to produce good macroeconomic outcomes, but it is important to have a strong commitment to develop these institutions and continuing vigilance that fiscal, financial and monetary institutions will continue to be strengthened.

\section{DEALING WITH EXCHANGE RATE FLUCTUATIONS}

The special features of emerging market economies outlined in the first section of the paper suggests that emerging market countries are likely to have greater concerns about exchange rate fluctuations than advanced countries do. Because of their past history and lower credibility in their ability to keep inflation under control, emerging market countries are more likely to find that depreciations lead to a rise in inflation as a result of the pass through from higher import prices and greater demand for exports.

In addition, liability dollarization means that depreciations are particularly dangerous because they can trigger a financial crisis along the lines suggested in Mishkin (1996, 1999). These countries have much of their debt denominated in foreign currency and when the currency depreciates, this increases the debt burden of domestic firms. Since assets are typically denominated 
in domestic currency and so do not increase in value, there is a resulting decline in net worth. This deterioration in balance sheets then increases adverse selection and moral hazard problems, which leads to financial instability and a sharp decline in investment and economic activity. This mechanism explains why the currency crises in Chile in 1982, Mexico in 1994-95, East Asia in 1997, Ecuador in 1999, Turkey in 2000-2001 and Argentina in 2001-2002 pushed these countries into full-fledged financial crises, which had devastating effects on their economies.

Given the potential devastating impact of currency depreciation on the financial system and the possibility that it will lead to a burst of inflation means provides a reason for central banks in emerging market countries not to pursue benign neglect of exchange rates even when they are inflation targeting. In order to prevent sharp depreciations of their currencies, which can destroy balance sheets and trigger a financial crisis, central banks in these countries may have to smooth exchange rate fluctuations. However, there is a danger that monetary policy, even under an inflation-targeting regime, may put too much focus on limiting exchange rate movements. The possibility of "fear of floating" (Calvo and Reinhart, 2002) when emerging market countries engage in inflation targeting is a real one.

The first problem with too strong a focus on limiting exchange rate movements is that it runs the risk of transforming the exchange rate into a nominal anchor that takes precedence over the inflation target. This has been a problem recently in Hungary, a transition country which has an exchange rate target as part of its inflation targeting regime (Jonas and Mishkin, 2003). For example, when the Hungarians adopted inflation targeting in July 2001, they retained an exchange rate band \pm 15 percent. Pursuing two nominal objectives could result in a situation where one objective will need to be given preference over the second objective, but without a clear guidance 
how such conflict would be resolved. This is likely to make monetary policy less transparent and hinder the achievement of the inflation target. Indeed, this is what has happened in Hungary In January 2003, the forint appreciated to the upper end of the band, and speculation about the revaluation of the parity resulted in a sharp acceleration of capital inflows that forced the National Bank of Hungary to respond by cutting interest rates by 2 percentage points and intervening heavily in the foreign exchange market. The National Bank of Hungary is reported to have bought more than 5 billion euros, increasing international reserves by 50 percent and base money by 70 percent. $^{12}$ Even though the National Bank of Hungary began subsequently to sterilize this huge injection of liquidity, market participants then assumed that maintaining the exchange rate band would have a priority over the inflation target and expected inflation in 2003 to exceed the National Bank of Hungary's inflation target.by 5 percentage points.. ${ }^{13}$ The outcome was that in 2003 Hungary did indeed overshoot its target, but by a somewhat smaller 2.2 percentage points. ${ }^{14}$

The second problem from too strong a focus on limiting exchange rate fluctuations is that the impact of changes in exchange rates on inflation and output can differ substantially depending on the nature of the shock that causes the exchange rate movement. Different monetary policy responses therefore depend on the nature of the shock. If the domestic currency depreciates because of a pure portfolio shock, inflation is likely to rise and the appropriate response to keep inflation under control is for the monetary authorities to tighten monetary policy and raise interest rates. In

${ }^{12}$ See J.P. Morgan (2003).

${ }^{13}$ Analysts have interpreted this as an evidence that the NBH is determined to maintain the currency band even at the cost of temporary higher inflation. See IMF (2002).

${ }^{14}$ Israel also had a fairly tight exchange rate band during the early years of its inflation targeting regime and this caused it to experience similar difficulties. See Bernanke, Laubach, Mishkin and Posen (1999) and Leiderman (2000). 
emerging market countries which have substantial liability dollarization, tightening monetary policy to prevent a sharp depreciation may be even more necessary to avoid financial instability (for the reasons mentioned above). On the other hand, if the exchange rate depreciation occurs because of real shocks, the impact is less likely to be inflationary and a different monetary policy response is warranted, but even here it depends on the nature of the shock. A negative terms-of-trade shock, which lowers demand for exports, reduces aggregate demand and is thus likely to be deflationary. In this situation, the correct interest rate response is to lower interest rates to counteract the drop in aggregate demand, and not to raise interest rates.

The mistakes that the Chilean central bank made in 1998 illustrates how serious the second problem can be. Chile's inflation targeting regime also included a focus on limiting exchange rate fluctuations by having an exchange rate band with a crawling peg which was (loosely) tied to lagged domestic inflation. Instead of easing monetary policy in the face of the negative terms-of-trade shock, the central bank raised interest rates sharply and even narrowed its exchange rate band. In hindsight, these decisions were a mistake: the inflation target was undershot and the economy entered a recession for the first time in the 1990s. ${ }^{15}$ With this outcome, the central bank came under strong criticism for the first time since it had adopted its inflation targeting regime in 1990, weakening support for the independence of the central bank and its inflation targeting regime. During 1999, the central bank did reverse course, easing monetary policy by lowering interest rates

\footnotetext{
${ }^{15}$ Given its location in Latin America, Chile's central bank did have to worry about a loss of credibility from exchange rate deprecation. Also because Chile encountered a sudden stop of capital inflows at the time, the ability of the Chilean central bank to pursue countercyclical policy was limited. However, although lowering interest rates in 1998 may not have been as attractive an option as it was in a country like Australia, which responded to the terms-of-trade shock by easing monetary policy, the sharp rise in the policy interest rate in 1998 was clearly a policy mistake.
} 
and allowing the peso to decline, and in May 2000 it revised its inflation targeting regime to reduce its focus on exchange rates.

The conclusion from the discussion here is that there is a rationale for central banks in emerging market countries to smooth exchange rates, but they can go to far. To cope with potential problems of financial instability, but preserve the focus on inflation control, central banks could increase the transparency of any intervention in the foreign exchange market by making it clear to the public that the purpose of the intervention is to smooth "excessive” exchange-rate fluctuations and not to prevent the exchange rate from reaching its market-determined level over longer horizons. However, continuing exchange market interventions, particularly unsterilized ones, are likely to be counterproductive because they are not transparent. Instead, exchange rate smoothing via changes in the interest rate instrument will be more transparent and indicate that the nominal anchor continues to be the inflation target and not the exchange rate. Central banks could also explain to the public the rationale for exchange rate intervention in a manner analogous to that for interest-rate smoothing, i.e., as a policy aimed not at resisting market-determined movements in an asset price, but at mitigating potentially destabilizing effects of abrupt and sustained changes in that price.

It is also important for central banks to recognize that the pass-through from exchange rate changes to inflation is likely to be regime dependent. After a sustained period of low inflation engineered by an inflation targeting regime, the affect of the exchange rate on the expectationsformation process and price setting practices of households and firms in the economy is likely to 
fall. ${ }^{16}$ Thus, inflation targeting is likely to help limit the pass-through from exchange rates to inflation and the view that a currently high pass-through is a barrier to successful inflation targeting is unwarranted.

\section{HOW CAN THE IMF HELP?}

A theme in both this and my recent paper with Guillermo (Calvo and Mishkin, 2003) is that developing strong fiscal, financial and monetary institutions is the key to successful macroeconomic policy. One way the IMF can help emerging market countries who choose to inflation target is to provide them with better incentives to develop these institutions. Instead of trying to impose a large number of conditions on countries as when the IMF lending program is put into effect, the IMF can provide the right incentives by being more willing to extend programs ex ante to countries who are making a serious attempt at reform, while saying no to governments who are unwilling to do so.

In addition, the IMF conditions for evaluating monetary policy under its programs can be modified to reflect the special features of inflation targeting regimes. In the past, a key element of IMF conditionality was ceilings on the growth rate of net domestic assets. Unfortunately, net domestic assets conditionality which is derived under the IMF's “financial programming” framework is based on an outdated theory, the monetary approach to the balance of payments (see Mussa and Savastano, 1999), which requires that the growth rate of monetary aggregates is closely

\footnotetext{
${ }^{16}$ See Muinhos (2001), Frenkel (2002) and Minella, de Freitas, Goldfajn and Muinhos
} (2002, 2003). 
linked to inflation. However, the linkage between monetary aggregates and inflation is almost always found to be very weak when inflation rates are reasonably low as is the case for emerging market countries that have adopted inflation targeting. As a result targets for net domestic asset targets are likely to lead to inappropriate setting of monetary policy instruments and are likely to decrease monetary policy transparency.

In an inflation targeting regime, it seems natural to replace net domestic asset conditionality with assessment of the country's inflation performance. Indeed, this is what the IMF moved to in evaluating monetary policy under its program for Brazil when inflation targeting was adopted in 1999. The IMF program has conducted quarterly reviews on how well Brazil has done in meeting its inflation targets, but there is still a problem that the IMF evaluation is essentially backward looking (Blejer, Leone, Rabanal, and Schwartz, 2001)

Inflation targeting is inherently forward-looking so the issue arises as to how IMF conditionality might be modified to be more forward looking. One approach would be for the IMF to monitor monetary policy institutions. Specifically, the IMF conditions could focus on the degree of central bank independence, whether the central bank mandate focuses on price stability as the long-run overriding goal of monetary policy, and whether transparency and accountability of the central bank is high. As part of this monitoring, the IMF could conduct a careful assessment of central bank procedures as to the legitimacy of its forecasting process and whether the central bank provides adequate explanations for misses of its inflation targets. In a sense this shift in approach is similar to the shift in approach that has occurred in bank supervision in recent years. In the past bank supervision was also quite backward looking in that it focused on the current state of banks' balance sheets. However, this backward-looking approach is no longer adequate in today's world, 
in which financial innovation has produced new markets and instruments that make it easy for banks and their employees to make huge bets easily and quickly. In this new financial environment, a bank that is quite healthy at a particular point in time can be driven into insolvency extremely rapidly from trading losses, as forcefully demonstrated by the failure of Barings in 1995. Thus bank examinations have now become far more forward looking and now place much greater emphasis on evaluating the soundness of a bank's management processes with regard to controlling risk. Similarly, the IMF could shift its conditionality to focus on the management processes in central banks to keep inflation under control.

\section{CONCLUDING REMARKS}

It has been my honor have Guillermo Calvo as a close friend for over twenty years, ever since he helped recruit me to come to Columbia Univeristy. Guillermo has always cared deeply about applying economic analysis to promote better outcomes in emerging market countries and his work has been an inspiration to me. This paper expands on many themes in Guillermo's research. The bottom line from the analysis here is that inflation targeting can be an effective tool for emerging market countries to manage their monetary policy. However, to ensure that inflation targeting produces superior macroeconomic outcomes, emerging market countries would benefit by focusing even more attention on institutional development, while international financial institutions like the IMF can help by providing these countries with better incentives to engage in this development. The hope is that this will lead to better economic performance in these countries over the coming years. 


\section{REFERENCES}

Bernanke, B., T. Laubach, F. Mishkin, and A. Posen, 1999, Inflation Targeting: Lessons from the International Experience, Princeton, NJ: Princeton University Press

Bernanke, Ben S. and Frederic S. Mishkin (1997). "Inflation Targeting: A New Framework for Monetary Policy?” Journal of Economic Perspectives 11(2): 97-116.

Blejer, Mario I., Alfredo M. Leone, Pau Rabanal, and Gerd Schwartz (2001), "Inflation Targeting in the Context of IMF-Supported Adjustment Programs", IMF Working Paper no. 01/31, March.

Brash, Donald T. 2000. "Inflation Targeting in New Zealand, 1988-2000," Speech to the TransTasman Business Cycle, Melbourne, February 9.

Burnside, Craig, Martin Eichenbaum and Sergio Rebelo (2001). "Prospective Deficits and the Asian Currency Crisis,” Journal of Political Economy 109(6): 1155-1197.

Caballero, Ricardo J. and Arvind Krishnamurthy (2002). "Excessive Dollar Debt: Financial Development and Underinsurance,” mimeographed, MIT.

Calomiris and Andrew Powel (2000) "Can Emerging Market Bank Regulators Establish Credible Discipline? The Case of Argentina, 1992-1999” NBER Working Paper 7715

Calvo, Guillermo A. (1999a) “Capital Markets and the Exchange Rate,” mimeo, University of Maryland, October

Calvo, Guillermo A. (1999b). "Contagion in Emerging Markets: when Wall Street is the carrier,” mimeographed, University of Maryland.

Calvo, Guillermo A. (2001). "Capital Markets and the Exchange Rate: with Special Reference to the Dollarization Debate in Latin America,” Journal of Money, Credit, and Banking 33(2): 312-334.

Calvo, Guillermo A., Alejandro Izquierdo and Ernesto Talvi (2002). "Sudden Stops, the Real Exchange Rate and Fiscal Sustainability: Argentina’s Lessons,” IADB Working Paper No. 469.

Calvo, G. and E. Mendoza, 2000, “Capital-Market Crises and Economic Collapse in EmergingMarkets: An Informational-Frictions Approach,” mimeo, Duke University and University of Maryland, January

Calvo, Guillermo and Frederic S. Mishkin, "The Mirage of Exchange Rate Regimes for Emerging Market Countries," Journal of Economic Perspectives, Vol. 17, No. 4 (Fall 2003). 
Calvo, Guillermo A. and Carmen M. Reinhart (2000). "When Capital Flows Come to a Sudden Stop: Consequences and Policy,” in Peter B. Kenen and Alexander K. Swoboda, eds., Reforming the International Monetary and Financial System (Washington, DC: IMF).

Calvo, Guillermo A. and Carmen M. Reinhart (2002). "Fear of Floating” Quarterly Journal of Economics 117(2): 379-408.

Calvo, Guillermo A. and Carlos A. Végh (1996). "From Currency Substitution to Dollarization and Beyond: Analytical and Policy Issues,” in Guillermo A. Calvo, Money, Exchange Rates, and Output (Cambridge, MA: The MIT Press): 153-175.

Caprio, Gerald, Jr. (1998). "Banking on Crises: Expensive Lessons from Recent Financial Crises,” World Bank Working Paper No. 1979,

Caprio, G. and D. Klingebiel, 1999. "Episodes of Systemic and Borderline Financial Crises,” World Bank, mimeo, October

Cukierman, Alex, 1992. Central Bank Strategy, Credibility and Independence: Theory and Evidence (Cambridge, Mass.: MIT Press).

Debelle, Guy and Stanley Fischer (1994). “How Independent Should a Central Bank Be?” in Jeffrey C. Fuhrer, ed., Goals, Guidelines, and Constraints Facing Monetary Policymakers, Conference Series 38 (Boston: Federal Reserve Bank of Boston): 195-221.

De Gregorio, Jose, Sebastian Edwards and Rodrigo O. Valdes (2000). “Controls on Capital Inflows: Do They Work?” NBER Working Paper No. w7645.

Dell'Ariccia, Giovanni, Isabel Gödde and Jeromin Zettelmeyer (2000). “Moral Hazard and International Crisis Lending: A Test,” mimeographed, International Monetary Fund.

Demirguc-Kunt, Asli and Edward J. Kane (2002). "Deposit Insurance around the Globe: Where Does it Work?” Journal of Economic Perspectives 16(2): 175-195.

Edwards, S., 1999, “How Effective are Controls on Capital Inflows? An Evaluation of Chile’s Experience,” mimeo, UCLA, June

Eichengreen, Barry, Ricardo Hausmann and Ugo Panizza (2002). "Original Sin: The Pain, the Mystery, and the Road to Redemption,” presented at the conference Currency and Maturity Matchmaking: Redeeming Debt from Original Sin, IADB, Washington, DC, November 21-22.

Fischer, Stanley (1994). "Modern Central Banking,” in Forrest Capie, Charles A. E. Goodhart, Stanley Fischer, and Norbert Schnadt, eds., The Future of Central Banking: The Tercentenary Symposium of the Bank of England (Cambridge, MA: Cambridge University Press): 262-308. 
Fraga, Arminio, Goldfajn Ilan and Minella André Minella, 2003, “Inflation Targeting in Emerging Market Economies” NBER Macro Annual, forthcoming.

Frenkel, Jacob (2002) “The Transition to Inflation Targeting” in in Banco de Mexico, Stabilization and Monetary Policy: The International Experience (Bank of Mexico: Mexico City).

Forder, James (2000) “Central Bank Independence and Credibility: Is There a Shred of Evidence?: Review” International Finance, vol. 3, no. 1, April: 167-85.

Garber, Peter (1999). "Hard-Wiring to the Dollar: From Currency Board to Currency Zone,” in Global Markets Research (London: Deutsche Bank).

International Monetary Fund (2002), Global Market Monitor, December 17.

Jeanne, Olivier (2002). “Why Do Emerging Economies Borrow in Foreign Currency?” presented at the conference Currency and Maturity Matchmaking: Redeeming Debt from Original Sin, IADB, Washington, DC, November 21-22.

Jeanne, Olivier and Jeromin Zettelmeyer (2001). “International Bailouts, Moral Hazard, and Conditionality,” Economic Policy 33: 409-432.

Jonas, Jiri and Frederic S. Mishkin (2003) "Inflation Targeting in Transition Countries:

Experience and Prospects," NBER Working Paper No. 9667 (May), forthcoming in Michael Woodford, ed., Inflation Targeting (University of Chicago Press: Chicago)

Kaminsky, Graciela L, Reinhart, Carmen M, and Carlos A. Vegh (2003). "The Unholy Trinity of Financial Contagion,” Journal of Economic Perspectives, forthcoming.

King, Mervyn, 1996. "How Should Central Banks Reduce Inflation?- Conceptual Issues," in Achieving Price Stability, Federal Reserve Bank of Kansas City, Kansas City, MO: 53-91.

Landerretche, Oscar, Felipe Morandé and Klaus Schmidt-Hebbel (1999). "Inflation Targets and Stabilization in Chile,” Central Bank of Chile Working Paper No. 55.

Leidermann, Leonardo (2000), “Inflation Targeting Under a Crawling Band: Lessons from Israel,” in Mario Blejer et al. (eds), "Inflation Targeting in Practice: Strategic and Operational Issues and Application to Emerging Market Economies.” International Monetary Fund, Washington, D.C.

Masson, P., M. Savastano, and S. Sharma, 1997, “The Scope for Inflation Targeting in Developing Countries,” IMF Working Paper 97/130, October

Minella André, Paulo Springer de Freitas, Ilan Goldfajn, and Marcelo Kfoury Muinhos (2002) "Inflation Targeting in Brazil: Lessons and Challenges” Banco Central do Brazil Working Paper 53, Nov. 2002 
Minella André, Paulo Springer de Freitas, Ilan Goldfajn, and Marcelo Kfoury Muinhos (2003) "Inflation Targeting in Brazil: Constructing Credibility under Exchange Rate Volatility" Banco Central do Brazil Working Paper 77, Dec. 2003

Mishkin, Frederic S. (1996). "Understanding Financial Crises: A Developing Country Perspective," Annual World Bank Conference on Development Economics: 29-62.

Mishkin, Frederic S. (1999). “Lessons from the Asian Crisis,” Journal of International Money and Finance 18(4): 709-723.

Mishkin, Frederic S. (2003) "Financial Policies and the Prevention of Financial Crises in Emerging Market Countries," in Martin Feldstein, ed., Economic and Financial Crises in Emerging Market Countries (University of Chicago Press: Chicago): 93-130.

Mishkin, Frederic S. and Miguel Savastano (2001). "Monetary Policy Strategies for Latin America," Journal of Development Economics 66(2): 415-444.

Mishkin, Frederic S. And Miguel Savastano, 2002. "Monetary Policy Strategies for Emerging Market Countries: Lessons from Latin America," Comparative Economic Studies Vol. XLIV, No. 2 (Summer 2002): 45-83.

Morgan, J.P. (2003), Emerging Europe, Middle East \& Africa Weekly, January 31.

Muinhos, Marcelo Kfoury (2001) "Inflation Targeting in an Open Financially Integrated Emerging Economy: the case of Brazil” Banco Central do Brazil Working Paper 26, August 2001

Mussa, Michael (1986). "Nominal Exchange Rate Regimes and the Behavior of Real Exchange Rates: Evidence and Implications,” Carnegie-Rochester Conference Series on Public Policy 25: 117-213.

Mussa, Michael and Miguel Savastano (1999) "The IMF Approach to Economic Stabilization," NBERMacro Annual 1999: 79-121.

Perry, Guilermo, John Whalley and Gary McMahon (2000) "Fiscal Reform and Structural Change in Developing Countries” v.2 St. Martin’s Press, New York 2000

Sargent, Thomas and Neil Wallace (1981). “Some Unpleasant Monetarist Arithmetic,” Federal Reserve Bank of Minneapolis Quarterly Review, 1-17.

Svensson, Lars O. (1997). "Inflation Forecast Targeting: Implementing and Monitoring Inflation Targets,” European Economic Review 41: 1111-1146. 
Tanzi, Vito (2000) Rationalizing the Government Budget or Why Fiscal Policy Is so Difficult” in in Anne Krueger, ed. Economic Policy Reform: The Second Stage (University of Chicago Press: Chicago, 2000).

Woodford, Michael (1994). "Monetary Policy and Price Level Determinacy in a Cash-inAdvance Economy,” Economic Theory 4: 345-380.

Woodford, Michael (1995). "Price Level Determinacy without Control of a Monetary Aggregate,” Carnegie-Rochester Conference Series on Public Policy 43: 1-46. 